\title{
RIVALRY ON THE RIGHT: THE CONSERVATIVES, THE UK INDEPENDENCE PARTY (UKIP) AND THE EU ISSUE
}

The 2010 general election provided further evidence of the development of multi-party politics in the United Kingdom. The Conservatives and Labour polled a combined post-war low of 65 per cent of the vote while small parties together scored 12 per cent but remained significantly underrepresented in the House of Commons. Having fallen short of a parliamentary majority, the Conservatives entered coalition with the Liberal Democrats. Beyond Westminster, multi-party politics is the norm in elections to the devolved assemblies, the European Parliament and many local authorities.

The presence of niche parties changes the parameters of party competition. Meguid (2005) identifies green, ethno-regionalist and radical right parties as niche parties - that is, parties with a distinctive focus on a limited set of non-economic issues which lie beyond the traditional class cleavage and are largely ignored by mainstream parties. Adams et al $(2006,513)$ use a broader definition of niche parties as non-centrist or ideologically extreme parties, as does Wagner (2011, 3) who highlights their focus on non-economic issues. Hard Eurosceptic parties oppose European integration as embodied in the European Union (EU) or adopt policies tantamount to the current EU project (Taggart and Szczerbiak's 2008, 247-8). These parties do not feature prominently in this literature but, given their location on an anti-European integration versus pro-European integration cleavage and focus on an issue often ignored by mainstream parties, they fit the niche party criteria. However, hard Eurosceptic parties are not part of a coherent or extensive party family: hard Euroscepticism is found across the ideological spectrum and may be one of a set of positions rather than a party's guiding ethos. Although the EU issue remains their primary concern, the extension of EU competences has seen some hard Eurosceptic parties broaden their 
focus. Hard Eurosceptic parties might thus be treated as a distinctive sub-set of niche parties (Lynch et al, 2011).

This article adds to the literature on party competition by examining the different strategies employed by mainstream and niche parties, using the Conservatives and UK Independence Party (UKIP) as a case study. European integration is the key issue in competition between the two, with UKIP supporting withdrawal from the EU. Formed in 1993, UKIP is now the UK's fourth largest party although its 2010 general election performance - winning 3.2 per cent of the vote and faring no better than third place in four constituencies - was disappointing for the party having come second in the 2009 European election. UKIP briefly overtook the Liberal Democrats in some opinion polls in spring 2012 with commentators warning that it could damage the Conservatives' election prospects (Montgomerie, 2012). Recent research has detailed the characteristics and attitudes of UKIP supporters (Lynch et al, 2011; Whitaker and Lynch, 2011; Ford et al, 2012), but competition between the Conservatives and UKIP remains underexplored.

Theories of competition between mainstream and niche parties suggest that the latter face a trade off between broadening their narrative in an attempt to win office and losing the support of core voters (Ezrow, 2008). Mainstream parties face choices about whether to ignore competition from niche rivals, adapt their own policies accordingly, or stay the course while emphasising differences between their position and that of the niche competitor. Meguid (2005) examines how mainstream parties respond to niche party success but not how niche parties in turn respond to the strategies of their mainstream rivals. This article seeks to do both in the case of the Conservatives and UKIP.

This article also adds to the literature on Euroscepticism and EU voting by examining competition between a mainstream soft Eurosceptic party and a smaller hard Eurosceptic party 
using the niche-mainstream party framework. Hard Euroscepticism involves principled opposition to European integration, whereas soft Euroscepticism is qualified opposition to the further transfer of competences to the EU (Taggart and Szczerbiak's 2008, 247-8). ConservativeUKIP competition is an unusual case of rivalry between a soft Eurosceptic governing party and a hard Eurosceptic niche party. Most governing parties tend to be pro-European with hard Eurosceptic parties located at the extremes (Ray, 2007; Conti and Memoli, 2012). The Conservative Party has, however, become more Eurosceptic over time and includes a small, but growing, group of MPs who publically endorse withdrawal from the EU and a larger number advocating renegotiation of British membership (Lynch and Whitaker, forthcoming).

A range of methods are used to examine Conservative-UKIP competition, including nonattributable interviews with politicians and officials from both parties, surveys of 2010 general election candidates from both, and analysis of manifestos and opinion poll data. Surveys of candidates were conducted using the online tool Survey Monkey. Emails were sent to candidates in three waves before, during and after the 2010 campaign, with postal surveys sent where email addresses were unavailable. The response rate for UKIP candidates was 53 per cent $(n=295)$ and 15 per cent $(n=94)$ for the Conservatives. ${ }^{1}$

A number of caveats are required. The focus on the Conservatives and UKIP does not imply that David Cameron's modernisation project was flawed because it moved the Conservatives to the centre to compete with Labour. This was necessary, but not sufficient, for the Conservatives to regain power. However, the Conservatives' move to the centre and downplaying of the EU issue created space that UKIP has exploited. Nor do we suggest that the UKIP challenge is the main driver of Conservative strategy on the EU issue. Intra-party divisions and competition with Labour have been more significant, but Conservative responses to these also shaped its strategy towards UKIP. Finally we are not suggesting that UKIP takes votes exclusively from the 
Conservatives or that the EU issue is the only reason for Conservative defections. UKIP attracts a range of voters dissatisfied with the main parties and concerned about immigration (Lynch et al, 2011; Ford et al, 2012), but coalition enhances UKIP's prospects of attracting disaffected Conservatives.

The first section of the article sets out key theories of party competition and EU issue voting, establishing our expectations for this case study. The second looks at UKIP's position and support. The article then analyses the approaches of UKIP and the Conservatives to competition with each other in general elections.

\section{Party competition}

There are three main theories of party competition. The spatial account states that parties move their position along the left-right ideological dimension and maximise support by positioning themselves close to the median voter (Downs, 1957). Voters choose the party closest to their policy preferences. With the narrowing of ideological differences and decline of partisanship, the valence model (Stokes, 1963) has become more effective in explaining election outcomes (Sanders et al, 2011). It focuses on voters' judgements of the competence of parties and their leaders to deliver policy goals that are widely accepted. A third approach focuses on parties manipulating the salience of issues (Budge and Farlie, 1983). Parties establish issue ownership when they are judged better able to handle the issue than their rivals (Petrocik, 1996; Green and Hobolt, 2008). They emphasise issues on which they are seen as competent and avoid those on which rivals are strong.

These theories focus on major parties. The strategic choices facing niche parties differ. The spatial model suggests that moving closer to the median voter brings electoral reward, but 
research shows that niche parties lose support and experience internal divisions if they moderate their core position (Adams et al., 2006; Ezrow, 2008). It is difficult for niche parties to establish a reputation for competence outside government, thereby disadvantaging them if valence judgements are based on performance rather than future prospects. Their optimal strategy is to establish their core issue as a positional issue, emphasising their distinctive position and distance from mainstream parties, and to raise the issue's salience (Wagner, 2012). Differences between niche and mainstream party strategies are also apparent in the relative importance they attach to policy, office and vote objectives (Strøm and Muller, 2000). Policy objectives are especially important for niche parties given their origins as a radical voice on a new issue and the strong feelings this engenders for members and supporters. We would thus expect UKIP to prioritise its distinctive position on the EU issue, but niche parties lack the resources to set the agenda. If the salience of the EU issue remains low and UKIP has aspirations of office, we would expect it to broaden its narrative and develop distinctive positions on other issues (Lynch et al, 2011).

Meguid (2005) and Bale et al (2010) examine the strategic response of mainstream parties. Meguid identifies three strategic responses and examines how these affect issue salience, position, ownership and niche party vote share. Mainstream parties may adopt a dismissive strategy, ignoring the niche party's core issue if they find it unimportant or difficult, thus lowering its salience and reducing support for the niche party. This may be problematic, however, if a major competitor adopts an adversarial strategy towards the niche party, thus emphasising the latter's core issue (Meguid, 2005, 351). An alternative is to adopt an accommodative strategy in which a mainstream party acknowledges the importance of the issue, moves towards the niche party's position and attempts to establish issue ownership, thereby lowering the niche party's vote share. Finally, an adversarial strategy sees a mainstream party oppose the niche party's stance but this reinforces the latter's ownership of the issue. 
In their study of social democratic party responses to the radical right, Bale et al (2010) identify three similar approaches and explain the circumstances in which they are used. Adapted to the more general case of niche versus mainstream party competition, the first suggests that if the niche party threat is not deemed significant enough to affect the mainstream party's vote share, the latter will hold its position, reinforcing its policy on the niche party's core issue, mobilising support and facing down the challenger. Alternatively, if the niche party challenge is viewed as serious, the mainstream party may attempt to defuse the niche party's issue, reducing its salience and focusing on other issues. Finally, if the threat is perceived as large enough to prevent the mainstream party from entering government, it will adopt the niche party's position and seek to maximise support, although this may cause internal divisions and damage its credibility.

Applying this to the case of the Conservatives and UKIP, if the threat from UKIP increases we would expect the Conservatives to move from holding their position to attempting to defuse the EU issue. Holding position is equivalent to Meguid's adversarial strategy in that the mainstream party sticks to its original approach which differs from that of the niche party. Following Meguid, this should increase the issue salience and benefit UKIP in terms of issue ownership and vote share. Defusing is similar to Meguid's dismissive approach on the basis of which we would expect the salience of the issue to decline, little change in issue ownership and lower support for UKIP, provided Labour do not adopt a high profile pro-EU strategy.

These theories do not examine how niche parties in turn react to mainstream party strategies. To the extent that the mainstream party adopts a holding or adversarial strategy by maintaining a different position from its smaller competitor, we expect the niche party to take advantage by drawing attention to these differences, thereby adopting its own adversarial strategy. Niche parties may also go further than this by adding issues beyond their primary appeal to gain additional support. But this will depend on how far such a strategy provokes internal divisions 
and leads to a loss of the niche party's core voters. In our case, we therefore expect UKIP to both emphasise its distinctiveness from the Conservatives and attempt to broaden its appeal without exacerbating internal tensions. We also suggest that niche parties might adopt non-competitive strategies in which they prioritise policy objectives over vote-seeking and office-seeking objectives. So, UKIP may decide not to oppose the Conservatives if the latter move closer to their position on European integration. But, as we will see, offers of cooperation may be intended to exploit their rival's problems.

\section{EU issue voting}

Research on party positions on European integration provides important insights for our understanding of Conservative-UKIP competition. Specifically, a number of factors may affect party positions on the EU issue including ideology (Hooghe and Marks, 2009), the party system and electoral system (Ray, 2007), intra-party divisions (Gabel and Scheve, 2007), whether a party is in office (Conti and Memoli, 2012) and party strategy (Steenbergen and Scott, 2004). The latter is particularly significant, and is the focus of this article. Positional differences between the main parties increase the likelihood of EU issue voting. While the Conservatives and Labour have converged on the left-right dimension, their positions on the EU have diverged. From the late 1980s the Conservatives became more Eurosceptic and Labour more pro-European. Voters became more Eurosceptic but party identifiers polarised with Conservative supporters becoming more Eurosceptic than their Labour counterparts (Green, 2007, 2011). The emergence of Eurosceptic niche parties acting as political entrepreneurs (Hooghe and Marks 2009, 13; de Vries and Hobolt, 2012) also increases EU issue voting. In Britain, the Referendum Party and UKIP raised the profile of the EU issue at the 1997 election, but the Conservatives also campaigned on it. Conversely, an absence of partisan conflict, efforts by parties to lower the salience of the issue, 
and dissent within parties reduce the incidence of EU issue voting (de Vries, 2007; Clements and Bartle, 2009).

As predicted in the literature, neo-liberal and pro-sovereignty positions have pushed the Conservatives and UKIP towards Euroscepticism. Regarding electoral systems, the use of proportional representation for European elections gives smaller parties a greater chance of winning seats in the European Parliament than at Westminster. We expect divisions within the Conservative Party over European integration to affect strategy with the leadership reducing the salience of the issue and making policy compromises in an attempt to manage dissent (Lynch and Whitaker, forthcoming). In addition, the presence of the Conservatives in coalition government is expected to highlight the gap between their position and that of UKIP, with beneficial consequences for UKIP's support and issue ownership.

\section{The Conservatives and UKIP}

How close are the Conservatives and UKIP in political space, and do they draw upon a similar support base? Using a range of sources, we examine the ideological positioning of the two parties and the nature of UKIP's support in 2010.

\section{Party positions}

Party positions can be measured through manifesto coding, expert surveys and surveys of party elites (Steenbergen and Marks, 2007). Our coding of UKIP's 2010 manifesto using the Comparative Manifestos Project (CMP) methodology positioned it to the right of centre with a score of 5.0 where 0 is central and higher values represent more right-wing views. The CMP data for 2010 place the Conservatives at 17.5, the Liberal Democrats at 4.7 and Labour at $-1.5 .^{2}$ 
UKIP's position to the left of the Conservatives arises in part from the CMP coding scheme's classification of statements on democracy - such as UKIP's support for referendums - as left wing. Our analysis of the 2009 European election manifestos using the 2009 Euromanifesto coding scheme ${ }^{3}$ placed UKIP on the right at 17.4 but the Conservatives on the left at -3.7 . On European integration, where negative values represent Euroscepticism, the Conservatives were at -7.0 and UKIP at -58.7.

The Chapel Hill expert surveys estimate party positions on European integration and on two leftright dimensions (Bakker et al, 2012; Steenbergen and Marks, 2007). In the 2010 survey UKIP is placed slightly to the right of the Conservatives on the economic left-right scale, a gap of 0.5 on a scale of 0-10 (see Figure 1). The gap is bigger on the overall left-right scale with the Conservatives closer to the centre (7.1) and UKIP further to the right (8.8), presumably reflecting its stance on issues such as immigration. UKIP is the party nearest the Conservative position on European integration aside from the British National Party (BNP). ${ }^{4}$

\section{FIGURE 1 HERE}

In our candidate surveys, UKIP and Conservative candidates at the 2010 general election were asked to place themselves, their party, its voters and other parties on a left-right ideological scale (see Figure 2) (Lynch et al, 2011). Most UKIP respondents placed themselves, their party and its voters to the right of centre, with almost half locating UKIP on the centre right. Very few placed themselves, UKIP or its voters on either the left or far right. UKIP candidates positioned their party on average at 6.6 on the $0-10$ scale and their party's voters at 6.4 . Only 36 per cent of UKIP candidates placed the Conservatives on the right. Conservative candidates placed themselves at an average of 6.8 on the left-right scale, their party at 6.6 and their voters at $7.3 .^{5}$ The utility of the left-right spectrum for niche parties is limited because their position is best understood in 
relation to new issue cleavages. Individuals may also interpret right and left in different ways, and be reluctant to place themselves at the extremes. Nonetheless, the surveys indicate that UKIP candidates do not regard the Conservatives as right wing while Conservative candidates place UKIP to the right of Conservative voters.

Our surveys also included a scale measuring attitudes to European integration, where 0 is 'European integration has gone much too far' and 10 is 'the EU should become a federal state'. The mean score for UKIP candidates' self-placement was 0.2 , with similar scores for their positioning of the party (0.1) and UKIP's voters (0.6). UKIP candidates do not view the Conservatives as Eurosceptic, placing the party at a mean of 6.2 on the same scale. Conservative candidates see themselves (a mean of 2.2) as more Eurosceptic than their party (2.6) but less so than Conservative voters (1.7). ${ }^{6}$

In summary, expert judgement data and candidate surveys show UKIP and the Conservatives as close to each other but with UKIP at the Eurosceptic extreme of the European integration dimension. The manifesto based positions are less consistent but do not place UKIP far from the centre-right. This suggests that the Conservatives have not adopted UKIP's position on European integration and remain distinct from it, although they are closer to it than other parties except the BNP. On broader issues, UKIP are close to the Conservatives suggesting they are trying to compete on similar territory

FIGURE 2 HERE

UKIP performs best in areas where the Conservatives do well, notably in non-urban southern England, but has also achieved higher than average results in less prosperous areas where the BNP performs well (Curtice et al, 2010; Denver 2010). At the individual level, Euroscepticism 
was the main driver of support for UKIP at the 2009 European election (Whitaker and Lynch, 2011). 2010 UKIP voters agreed more strongly than voters of other parties that Britain should leave the EU, were more concerned about immigration and rated politicians as less honest than voters for the main parties (but not BNP voters). They were older, more likely to be male, from social classes C2, D and E, and have left education by age 18 (Lynch et al, 2011). UKIP voters were more likely to live in South West and Eastern England but less likely to reside in London and Scotland. There are fewer middle class voters among UKIP general election than European election supporters and the former have stronger anti-immigration and populist views, although less strong than those of BNP voters (Lynch et al, 2011; Ford et al, 2012). Ford et al (2012) thus describe UKIP's support as an uneasy coalition of 'strategic Eurosceptics' who vote for them in European elections to register their Euroscepticism and 'core loyalists' with stronger antiimmigration and populist views. We examine post-2010 changes in support for UKIP later in the article.

\section{UKIP}

This section considers how far UKIP have sought to broaden their appeal to win additional support from Conservative voters, in line with our expectations. We also consider whether UKIP have used adversarial and non-competitive strategies consistent with our suggestions about how niche parties react to mainstream parties' actions.

Euroscepticism has been central to UKIP's fortunes. It favours withdrawal from the EU and has tended to highlight the costs of EU membership rather than make a positive case for an alternative relationship. Ipsos MORI polls show a hardening of public opinion on EU membership, with 49 per cent of those surveyed in October 2011 saying they would vote to get out of the EU in a referendum compared to 41 per who would vote to stay in. ${ }^{7}$ 
To maintain success, small parties must strike an appropriate balance between policy, vote and office objectives (Spoon, 2009; Lynch et al, 2011). UKIP's leadership has recognised that, given the low salience of the EU issue, it must broaden its message if it is to win seats in local and national elections. Immigration is as a key issue for the party and its supporters. UKIP 2010 candidates favoured tougher immigration controls and UKIP voters regard immigration as the most important issue facing the country (Whitaker and Lynch, 2011). Immigration has been prominent in UKIP campaigns, the party proposing a five-year ban on immigration for permanent settlement. UKIP describes itself as a non-racist party, barring BNP and English Defence League members from joining. It claims to support civic nationalism, rejects 'multiculturalism and political correctness, and promotes uniculturalism - aiming to create a single British culture embracing all races, religions and colours' (UK Independence Party, 2010a).

Islamic extremism featured prominently in UKIP's discourse under Lord Pearson, party leader from 2009 to 2010. It proposed a ban on wearing the burqa in public places, although the distinction between public and private was lost in Pearson's description of the burqa as 'a symbol of separation, discrimination and fear' (The Times, 20 January 2010). The combination of Islamophobia, anti-immigration policies, populism and Euroscepticism has brought electoral success for populist radical right parties in Europe (Mudde, 2008). Ford et al. (2012) argue that UKIP's best prospect of building support is to become a 'polite alternative' to the BNP, mobilising alienated, anti-immigration voters who will not vote for the far right. However, the dilution of Conservative policies in coalition points instead to a strategy of persuading disillusioned Conservatives to vote UKIP in general elections as well as European elections.

Vigorously pursuing a radical right strategy risks contaminating the UKIP brand, deterring voters on the centre right and creating intra-party dissent. Since Farage's return to the leadership in late 
2010, the radical right turn has stalled. A 2011 policy statement did not include the burqa ban with Farage saying it is 'something that I have inherited to some extent ... It's a policy I'm going to look at' (Sparrow, 2011). Farage has also described the position on uniculturalism as 'pretty unhelpful. Hands up, we got it wrong' (www.mumsnet.com/Talk/mumsnet_live_events/1156236Live-webchat-with-UKIP-leader-Nigel-Farage-Thurs-24-Feb-1-2pm/AllOnOnePage). With the BNP beset by problems, UKIP might win support from anti-immigration voters without an overtly xenophobic pitch for support. Focusing on constraints on immigration policy imposed by the EU and European Convention on Human Rights might serve as a dog whistle to these voters. But UKIP is unlikely to depart from its uncompromising messages on immigration given the importance of the issue to its supporters.

Populist messages (Rooduijn et al, 2012) also feature heavily in UKIP's discourse, with the party highlighting 'a gulf [that] has opened between the ruling elite and the public' (UK Independence Party, 2011). This was evident in UKIP's campaign at the 2009 European election, which was dominated by the MPs' expenses scandal, and 2010 general election when UKIP encouraged voters to 'sod the lot'. This resonates with UKIP voters who, compared to voters for the main parties, have lower levels of trust in politicians and are more likely to believe that there are few differences between the main parties (Lynch et al, 2011). With the Liberal Democrats in government and the BNP in retreat, UKIP is better positioned to pick up protest votes.

Beyond populism, the themes of independence and self-government lend some coherence to UKIP policies. The party proposes greater use of referendums, and direct elections to police, education and health boards. UKIP had proposed to abolish the devolved assemblies but the leadership now favours an English Parliament, although there has been some internal opposition. This brings UKIP's position closer to that of the English Democrats, who also favour withdrawal from the EU and tough immigration controls. UKIP extols ultra-Thatcherite policies such as a flat 
tax, deeper public sector cuts, voucher systems in education and health, and boot camps for young offenders (UK Independence Party, 2010b). It claims that 'each of the establishment main parties are now social democrats and offer voters no real choice' (UK Independence Party, 2011). In the British Election Study's Continuous Monitoring Survey (CMS), conducted monthly with samples of around 1,000 people,$^{8} 17.6$ per cent of UKIP supporters surveyed between June 2010 and April 2012 thought that either 'big' or 'moderate tax increases are needed to help reduce the deficit', a lower figure than for Conservative (24.3 per cent), Liberal Democrat (31.5 per cent) and Labour (33.1 per cent) supporters. However, fewer UKIP supporters (65.3 per cent) than Conservative (90.9 per cent) and Liberal Democrat (70.8 per cent) supporters - but more than Labour (28.5 per cent) - strongly agreed or agreed that 'the government's cuts in public sector expenditure are essential for the long term health of the economy', indicating limits to their Thatcherite appetite.

A libertarian undercurrent is also coming to the fore. UKIP's new constitution defines it as a 'democratic, libertarian party' supporting individual self-reliance, a smaller state and lower taxes. There are, however, tensions between libertarians and authoritarians within UKIP and surveys indicate authoritarian attitudes are prevalent among their supporters. The survey conducted for Bethell (2010) included 1,000 UKIP and BNP supporters, while 1,406 UKIP supporters and 386 BNP supporters featured in that conducted for Goodwin and Evans (2012), although neither survey claims to be representative of UKIP support as a whole. Goodwin and Evans (2012, 1617) found that 57 per cent of UKIP supporters in their sample strongly agreed or agreed that 'censorship of films and magazines is necessary to uphold moral standards', while 81 per cent strongly agreed or agreed that 'for some crimes, the death penalty is the most appropriate sentence'. Bethell $(2012,17)$ found that 62 per cent of UKIP supporters tended to disagree or strongly disagreed that 'the government should do more to recognise gay marriage'. 
The expansion of UKIP's programme and support base takes it beyond Mudde's definition (1999, 184) of a single-issue party as one whose electorate has no particular social structure, is supported predominantly on the basis of a single issue, does not present an ideological position and addresses only one all-encompassing issue. But a number of factors work against a UKIP breakthrough. The party lacks the media support and resources of larger parties with only the Daily Express, which supports withdrawal from the EU, broadly supportive. It also faces organisational challenges. Charismatic leaders have contributed to niche party success in Europe (Mudde, 2008, 261-3). Had former Labour MP and television presenter Robert Kilroy-Silk become leader, UKIP may have followed this trajectory. But he failed to force a leadership challenge and left the party. Pearson, an old Etonian peer and poor media performer, was hardly a populist leader. Farage's third place in Buckingham in 2010, where none of the main parties stood, suggests limits to his popularity.

Niche parties that have won seats in local and general elections have maintained their distinctive message while targeting constituencies (Spoon, 2009). UKIP recognised the importance of building grassroots support and campaigning on local issues at a relatively late stage, and few branches have a critical mass of activists. A small party whose support is evenly distributed will struggle to translate votes into seats under the simple plurality electoral system. UKIP increased its vote share in the 2012 local elections but made no net gain of seats, having just 28 councillors in England. Second place in Barnsley Central in 2011 was only the third time that UKIP polled over 10 per cent in a Westminster by-election. Increased funding and greater central control may bring improvements but professionalization creates tensions between activists and the leadership (Abedi and Lundberg, 2009), evidenced in the rejection in a 2011 members' ballot of proposals for a pan-European party.

\section{Rivalry and its limits}


UKIP has adopted both adversarial and non-competitive approaches towards the Conservatives. In adversarial mode, it claims to be the authentic conservative voice on Europe, immigration, crime and taxation. UKIP also aims to undermine the credibility of the soft Eurosceptic position and steer debate towards a choice between the status quo and withdrawal. Its support for a referendum on EU membership is tactical, drawing attention to the failure of the main parties to deliver on referendum promises and opposition to an 'in-out' vote, and stoking internal dissent within them. There are limits to an adversarial approach. Kilroy-Silk urged the party to 'kill' a ‘dying' Conservative Party, prompting donor Paul Sykes to withdraw support (Farage 2010, 1825). Asking electors to 'lend us your vote' at the 2009 European election made a virtue of the party's record of attracting, albeit temporarily, disillusioned Conservatives.

Further limits to an overtly adversarial strategy have been evident in debates within UKIP as to whether it should field candidates in seats held by Eurosceptic MPs. An increased hard Eurosceptic presence at Westminster would increase the likelihood of a referendum on EU membership, thus furthering UKIP's policy objectives. In Farage's first spell as leader (2006-09), UKIP would not stand against MPs who publically supported the Better Off Out (BOO) campaign. It would challenge MPs who had not endorsed BOO and non-incumbent BOO supporters. This was muddied under Pearson who announced that UKIP would not stand against five Conservative MPs (all BOO supporters), independent MP Bob Spink and Labour MP David Drew. A UKIP challenger to Drew was already in place but he advised undecided voters to support Labour. Pearson asked other candidates to withdraw (they refused) and encouraged electors in three Somerset constituencies to vote Conservative. In our survey of 2010 UKIP candidates, 48 per cent agreed/strongly agreed that UKIP should stand against Eurosceptics but 26 per cent disagreed/strongly disagreed. UKIP also offered not to contest the 2010 general election if the Conservatives promised a binding referendum on EU membership. Since then, 
Farage has floated the idea of joint Conservative-UKIP candidates (Forsyth, 2012). These developments suggest a non-competitive strategy in which UKIP prioritises its policy objectives despite this being detrimental to its electoral prospects. However this is an adversarial strategy disguised as a cooperative one, designed to make the EU issue still more difficult for the Conservatives. It is doubtful that the UKIP leadership could deliver upon offers of cooperation and it would undermine efforts to shed UKIP's image as a single-issue party.

\section{Conservative Party}

How have the Conservatives reacted to UKIP? How far have they chosen to dismiss the party, accommodate its issue or adopt an adversarial stance? In reality, parties trade off elements of each of these strategies (Bale et al, 2010, 412). The Conservatives have thus not pursued one strategy consistently or in isolation: they have both developed their soft Eurosceptic position and defused the EU issue while limiting engagement with UKIP. Although few in the party advocated withdrawal, Europe was not a new issue for the Conservatives when UKIP emerged. Nor was the rise of UKIP the main driver of Conservative strategy on Europe: soft Euroscepticism and lowering of the salience of the EU issue arose primarily from intra-party divisions and inter-party competition with Labour. In this section we explore how the Conservatives have disregarded UKIP, adopted an adversarial approach and attempted to defuse the EU issue.

\section{Disregarding UKIP}

The Conservatives disregarded UKIP even as it gained support, giving voters the impression that UKIP was not a serious rival. This differs from the 'dismissive strategy' identified by Meguid (2005) in which a mainstream party downplays the merit of the niche party's issue. The deliberate disregard for the UKIP threat was an attempt to undermine the legitimacy of its niche competitor 
rather than the EU issue. Michael Howard thus described UKIP as 'cranks and political gadflies' (Helm, 2004) and Cameron called its members ‘fruitcakes, loons and closet racists' (Carlin, 2006). Such statements might make Conservative voters think twice about defecting, but risk offending those who sympathise with UKIP policies. The 'cranks and political gadflies' description originated in an internal document during a 2004 European election campaign in which the Conservatives were ill-prepared for the surge in support for UKIP. They were better prepared in 2009 when the Conservatives accused UKIP of failing to defend British interests in the EU, highlighted problems within UKIP ranks and noted that it could not achieve EU withdrawal through the European Parliament. Many Conservative Eurosceptics have been critical of UKIP. John Redwood argues that UKIP damages the prospects of a Eurosceptic government by splitting the Eurosceptic vote, while its poor domestic election performances foster claims that the EU is not an important issue for voters (Redwood, 2006, What is the point of UKIP?, http://johnredwoodsdiary.com/2006/12/15/john-redwood-on-ukip-taken-from-freedom-today$\underline{\text { article/). }}$

There is little incentive for the Conservatives to seek a national accommodation with UKIP given the latter's poor prospects of winning seats or becoming a potential coalition partner. Local agreements may, however, be in the interests of Conservative candidates and associations in constituencies where UKIP's presence might deny them victory. Pearson responded to pleas from some Conservatives by asking UKIP candidates to step down. In constituencies where UKIP did not stand against Eurosceptic Conservatives, Philip Hollobone appeared with Pearson on the campaign trail but others rebuffed offers of support.

\section{Developing soft Euroscepticism}


The Conservatives have developed a soft Eurosceptic position since the mid-1990s when John Major threatened to veto further transfers of powers, sought opt-outs and promised a referendum should his party recommend EMU entry. William Hague then developed an 'in Europe, not run by Europe' position with commitments to referendums on major EU treaties, a reaffirmation of parliamentary sovereignty and limited repatriation of EU policies. They were retained by Hague's successors and EMU policy was settled when Iain Duncan Smith ruled out entry. This soft Euroscepticism was distinctive from UKIP's withdrawalist position, consistent with an adversarial strategy (Meguid, 2005) or holding position (Bale et al, 2010).

Positional differences between the main parties became more pronounced as Conservative opposition to EMU and new EU treaties hardened. But the 2003 announcement that the five economic tests for EMU entry had not been met ended the prospect of entry in the medium term. The Conservatives portrayed themselves as best able to defend British interests and deliver EU reform and criticised Labour's record. Conservative discourse altered with opposition to the Constitutional Treaty and Lisbon Treaty framed in terms of democracy and trust rather than sovereignty and identity.

Cameron removed Conservative MEPs from the European People's Party-European Democrat Group in the European Parliament and formed a new group, the European Conservatives and Reformists. Cameron's claim that his pledge to hold a referendum on the Lisbon Treaty was a 'cast iron guarantee' proved problematic as when the treaty was ratified he announced that the Conservatives would not hold a 'made-up referendum' but negotiate further 'British guarantees' and 'restore key powers to Britain' (Cameron, 2009). The 2010 manifesto pledged to seek safeguards on EU social and employment policy, the Charter of Fundamental Rights and criminal justice (Conservative Party, 2010). A Conservative government would also introduce a Sovereignty Bill and 'referendum lock' requiring future British governments to hold a 
referendum on any treaty transferring powers to the EU. These soft Eurosceptic commitments were balanced by statements on the benefits of EU membership, contrasting the Conservative position with that of UKIP. This is consistent with a strategy of holding position and facing down the niche party (Bale et al, 2010).

A desire to avoid division within his party and confrontation in the EU has underpinned Cameron's Euroscepticism. He and his predecessors have employed policy compromises and referendum pledges, deferred decisions and lowered the salience of the issue to dampen internal tensions (Lynch and Whitaker, forthcoming). In competition with UKIP, this allows the Conservatives to appear Eurosceptic while avoiding clear positions. This vagueness driven by internal factors differs somewhat from the strategy of blurring - deliberate misrepresentation by a party of its position on an issue in competition with other parties - identified by Rovny (2012), but it similarly allows the Conservatives to appear closer to the views of its supporters than is the case.

\section{Defusing the EU issue}

Parties can encourage EU issue voting by providing cues to their supporters, raising the salience of the issue and offering a clear position. Conservative policy and personnel became more Eurosceptic in the 1990s, the positions of the Conservatives and Labour diverged and the EU issue became, for a time, more important for voters (Green, 2007). We might, then, expect the Conservatives to have to raise the salience of the EU issue. This was true in the 1997 and 2001 elections but not 2005 and, particularly, 2010. The proportion of negative statements on European integration in Conservative manifestos rose from 1992 but the trend is not uniform (Clements and Bartle, 2009) and the 2010 manifesto had a rough balance between negative and positive statements. But the overall proportion of statements about the EU has declined (see Figure 3), 
consistent with an attempt to reduce the salience of the issue. The Chapel Hill expert surveys also estimate the salience of European integration on a 1-4 scale where larger numbers represent higher salience. In 2010 this was higher for the Conservatives (2.7) than Labour (2.1) but lower than for UKIP (4.0). Consistent with the trends in the manifesto data, the 2010 figure for the Conservatives is lower than in 1999 (3.1). ${ }^{9}$

FIGURE 3 HERE

Internal divisions on an issue may lead a party to try to reduce its salience. They might also force party leaders to make policy compromises which make its position unclear to voters, reducing the chances of issue ownership (Gabel and Scheve, 2007). European integration produced serious divisions within the Conservative Party in the 1990s. In an attempt to dampen divisions, John Major adopted policy compromises and deferred key decisions, notably the 'negotiate and decide' ('wait and see') position on EMU. Hague adapted this to oppose EMU membership for two parliaments. Internal divisions and policy compromises left Eurosceptic voters unconvinced about the Conservatives' credentials (Evans 1998). Nevertheless, Europe was the number one issue in the Conservatives' 2001 campaign and the 2001 BES post-campaign survey showed that just over a quarter of Conservative voters thought Britain's relations with the EU or EMU was the most important issue in the election, with only the NHS equalling this among Conservative supporters. Of those identifying Britain's relations with the EU or EMU as the most important issue, 38.3 per cent said the Conservatives were the party best able to handle it, compared to 26.8 per cent for Labour and 5.4 per cent for the Liberal Democrats. ${ }^{10}$ Although raising the salience of European integration won over some Eurosceptics (Evans, 2002), only 12.8 per cent of voters overall rated it as the most important issue. 
Attempts to reduce an issue's salience in order to distract attention from intra-party divisions may not work when parties are significantly divided because factions prioritise the issue (Steenbergen and Scott, 2004, 185-6). During the 1997 election campaign, more than 200 Conservative candidates defied party policy to announce their opposition to EMU. The Conservatives thereafter became more united around a soft Eurosceptic position, although differences are evident over the scale and pace of change to relations with the EU (Lynch and Whitaker, forthcoming). Duncan Smith used his 2001 leadership election victory over pro-European Ken Clarke to rule out EMU membership and close the EU issue down. Howard followed suit and not 'banging on about Europe' was part of Cameron's project to decontaminate the Conservative brand. Labour also defused the issue by postponing a decision on EMU entry and promising referendums on EMU and the Constitutional Treaty (Oppermann, 2008). By taking EMU off the agenda, Labour reduced the scope for the Conservatives to exploit positional differences.

By 2005 competition with UKIP was of more concern given that it won 16 per cent of the vote at the 2004 European election. Europe was less prominent in the Conservatives' 2005 election campaign than in 2001, with the party focusing more on immigration. This strategy is consistent with a dismissive approach to UKIP who, according to the 2005 post-campaign BES internet survey, ${ }^{11}$ had overtaken the Conservatives as the party viewed as best able to handle the issue by those regarding Britain's relations with the EU or the euro as most important (35.3 per cent favoured UKIP, 30.0 per cent the Conservatives). But overall only 2.9 per cent of respondents cited this issue as 'most important'. The figure among Conservative voters was 4.4 per cent, much lower than in $2001,{ }^{12}$ compared with 20.8 per cent of UKIP voters and 1.8 per cent of Labour and Liberal Democrat voters. 22 per cent of Conservative voters favoured withdrawal from the EU (Green, 2007, 643), this gap between the party and some of its voters creating a further incentive for the Conservatives to downplay the EU issue (Matilla and Raunio, 2012). 
The EU issue was largely ignored by the main parties in the 2010 campaign (Carey and Geddes, 2010). Our survey of Conservative candidates found broad support for the low salience of the issue. Only 26.8 per cent of respondents agreed/strongly agreed (54.9 per cent disagreed/strongly disagreed) that 'the issue of European integration should feature prominently in the Conservatives' 2010 general election campaign'. 39.8 per cent agreed/strongly agreed that 'the issue of European integration is an important one for voters', and 78.1 per cent agreed/strongly agreed that it is 'a particularly important one for Conservative voters'. However, in the 2010 BES post-campaign internet survey only 0.7 per cent of Conservative voters identified Europe or the euro as the most important issue.

The BES 2010 survey also included a question about how much respondents agreed that Britain should cooperate more closely with the EU. Answers were on a five point scale where 1 is strongly agree and 5 strongly disagree. Conservative voters gave an average score of 4.1 compared to 3.0 for Labour and Liberal Democrat voters and 4.6 for UKIP voters. ${ }^{13} 12.1$ per cent of UKIP voters said that Europe or the euro was the 'most important issue facing the country at the present time'. Of those identifying Europe or the euro as the most important issue, UKIP appeared to have consolidated ownership in that 60.8 per cent believed it was the party best able to deal with the issue followed by 14.2 per cent for the Conservatives, 10.0 per cent for the BNP and 1.7 per cent each for Labour and the Liberal Democrats. ${ }^{13}$ Ipsos-MORI data show a decline in the proportion of voters regarding Europe as one of the main issues facing the country (see Figure 4). Developments in the EU produce fluctuations in salience, with upturns apparent at the time of the 2005 French and Dutch referendums on the Constitutional Treaty. Cameron's refusal to sign an EU fiscal compact treaty in December 2011 also produced a small increase. Taken together, these data suggest a considerable decline in the salience of the EU issue from 2001 to 2010 among voters overall and specifically among Conservative supporters, consistent with a dismissive strategy by the party. Among those identifying the EU issue as most important, the 
proportion of voters identifying UKIP as the party best able to handle the issue has increased. This may make the Conservatives more wary of stressing their Euroscepticism in competition with Labour for fear of drawing attention to UKIP's more radical position.

\section{FIGURE 4 HERE}

\section{Changing support for the Conservatives and UKIP}

What effect have the Conservatives' decisions to hold their position in policy terms and reduce the salience of the European issue had on support for UKIP? According to Meguid (2005), maintaining policy differences from the niche party should lead to greater support for the latter whereas reducing the issue's salience should have the opposite effect. Support for the Conservatives may also be affected by the party's policies being diluted in coalition and we expect UKIP's prospects of attracting disaffected Conservative supporters to improve. Opinion polls confirm that the Conservatives are leaking more support to UKIP than are other parties. Voting intentions of 2010 Conservative voters over time can be measured using the CMS. Combining monthly data from the June 2010 to May 2011 surveys, of those who claimed to have voted Conservative in 2010, 2.8 per cent said they would vote UKIP 'if there were a general election tomorrow'. Of those claiming to have voted Labour in 2010 the figure is only 0.5 per cent, and is 2.1 per cent for those who voted Liberal Democrat. Combined monthly data from June 2011 to April 2012 show bigger differences with 5.9 per cent of Conservative 2010 voters saying they would vote UKIP compared to 0.7 per cent of 2010 Labour supporters and 2.9 per cent of Liberal Democrats. YouGov reports a similar pattern, with support for UKIP rising from 2 per cent in 2010 to between 8 and 10 per cent after the 2012 budget. By then, more than 10 per cent of 2010 Conservative voters said that they would now vote UKIP with it, not Labour, the main destination for Conservative defectors. ${ }^{15}$ UKIP also most likely took support from the 
Conservatives at the 2012 local elections, winning an average of 13 per cent of the vote in wards it contested. While the reasons for this shift in support may be many and varied, and we do not claim that these are all down to differences in policy between the Conservatives and UKIP, the trends are as expected.

\section{Challenges of coalition}

Conservative manifesto commitments on EU policy repatriation were dropped during coalition negotiations with the Liberal Democrats. The European Union Act 2011 includes a 'referendum lock' ensuring that future treaties transferring powers from the UK to the EU will be subject to a referendum. But a referendum is unlikely during the current parliament as the coalition agreement rules out the transfer of competences. The government refused to join the European Stability Mechanism and Euro Plus Pact, and did not sign the Treaty on Stability, Coordination and Governance (the 'fiscal compact'). Cameron's veto boosted his and his party's standing in the polls, suggesting that the Conservatives might exploit the EU issue by claiming to be best able to defend British interests. But achieving EU policy success is difficult for soft Eurosceptic governments and tough decisions lie ahead on EU competences in criminal justice and policing, and the EU's 2014-20 multiannual financial framework. Intra-party divisions may also undermine claims to competence. The gap between the EU policy preferences of many Conservative MPs and coalition policy was exposed when 81 Conservatives rebelled on an October 2011 backbench motion supporting policy repatriation and a referendum. The rebellion was the largest ever on the EU issue (Cowley and Stuart, 2012), bringing together hard Eurosceptics favouring withdrawal, revisionists supporting renegotiation and those wanting a referendum on the EU. Intra-party dissent on Europe is also more likely in government than in opposition because individual governments cannot control the EU agenda, must take decisions on divisive issues and make compromises in EU negotiations (Lynch and Whitaker, forthcoming). Finally, many voters favour 
either withdrawal from the EU or fundamental renegotiation so are unlikely to be satisfied by coalition policy.

Pledging a referendum on Britain's relationship with the EU may prove popular with voters and Conservative MPs. Cameron (2009) indicated that he "would not rule out a referendum on a wider package of guarantees' should demands for repatriation fail but he has consistently opposed an 'in-out' referendum, maintaining that EU membership is in the national interest. A referendum mandating the government to pursue a limited renegotiation and/or a vote on the outcome of such negotiations are options for the next Conservative manifesto. The Fresh Start Project of Conservative MPs has published a 'Green Paper' (2012) on policy repatriation and a Foreign Office audit of competences is underway. Promising a referendum on repatriation might defuse the EU issue in the short-term, limit internal dissent and blunt some of UKIP's appeal. But it would create problems for a future Conservative government which may be unable to extract significant concessions from other EU Member States. Intra-party dissent would be exacerbated if, in a referendum, the Conservative leadership recommended a limited repatriation package while many MPs campaigned for withdrawal

Meguid (2005) finds that the position adopted by the 'non-proximate' mainstream party, in this case Labour, is significant in competition between mainstream and niche parties. Promising an 'in-out' referendum has attractions for Labour as it would further expose Conservative divisions, reinforce UKIP's threat to the Conservatives and allow Labour to court public opinion while maintaining a more pro-European position than the Conservatives. The likelihood is that if one of the main parties pledges a referendum, others will follow suit although the nature of the vote on offer may differ.

\section{Conclusions}


Our analysis of competition between UKIP and the Conservatives has shown the utility of the niche versus mainstream party framework for understanding competition between soft Eurosceptic and hard Eurosceptic parties, with the latter a distinctive sub-set of niche parties. Meguid (2005) identifies three strategies utilised by mainstream parties in competition with niche rivals: accommodative, adversarial and dismissive. The Conservatives have employed an adversarial or holding strategy by developing a soft Eurosceptic position. They have also adopted a dismissive or defusing strategy by lowering the salience of the EU issue, in part because of the party management difficulties the issue poses. The threat from UKIP in general elections has not been viewed by the Conservative leadership as so great that it should adopt UKIP's withdrawalist position, although changes in Conservative personnel and policy have seen the party take a more Eurosceptic position over the last twenty years.

Our case study shows, as Bale et al $(2010,413)$ suggest, that party competition is messier than implied by Meguid's ideal-typical strategies. The Conservatives have employed more than one strategy at the same time and have adopted slightly different approaches. They have disregarded their niche competitor, downplaying the UKIP threat, while recognising the importance of the EU issue to Conservative supporters. Furthermore, in developing their soft Eurosceptic position, the Conservatives have adopted policy compromises, pledged referendums and deferred decisions in order to dampen intra-party divisions (Lynch and Whitaker, forthcoming). But these vague positions can also be helpful in addressing the UKIP challenge.

The Conservatives and UKIP have adopted different strategies on the EU issue, the former lowering the issue's salience while the latter seeks to raise it. The issue has both positional and valence elements. In 1997 and 2001, the Conservatives' position on EMU was closer to public opinion than Labour's so highlighted these positional differences. The Conservatives also claimed 
to be the party best able to defend British interests in the EU, but intra-party divisions and mixed messages on the EU issue complicated their efforts to establish issue ownership. After 2001, the Conservatives continued to develop a distinctive soft Eurosceptic position but lowered the salience of the EU issue. Our findings provide further confirmation that a mainstream party is most likely to encourage EU issue voting when there are positional differences between the main parties, the issue is salient to voters and the party is regarded as better able to handle the issue than its rivals. A mainstream party is, however, unlikely to emphasise the EU issue if it is unimportant to voters, it has not established issue ownership, the party is divided on the issue and there is disconnect between its policy and the preferences of its supporters.

Judgements by voters of a party's performance in office have been crucial in recent elections (Sanders et al, 2011). Bale (2006) suggests that the Conservatives might exploit the EU as a valence issue by developing a soft Eurosceptic position in tune with public opinion. We might thus expect the Conservatives to highlight their EU policy record, but there are significant obstacles to an effective valence politics strategy on the issue. Governing parties may be less likely to stress the issue than opposition parties as it is difficult for governments to shape the EU agenda. Soft Eurosceptic governments also find it difficult to achieve EU policy successes. Furthermore, coalition has exposed both divisions within the Conservative Party and a gap between government policy and the preferences of Conservative voters.

If retrospective evaluations of EU issue competence are problematic, the Conservatives might promote prospective evaluations by promising policy repatriation and a referendum on Britain's relationship with the EU. This would be popular with Conservative voters and MPs, and would counter UKIP's appeal on these issues. However, a desire to avoid conflict on the EU issue in the Conservative Party and the EU has been a key feature of Cameron's pragmatic Euroscepticism. This suggests that the Conservatives are again unlikely to prioritise the EU issue. If the 
Conservatives are regarded as competent and the economy is improving, many supporters who have considered voting for UKIP are likely to return to the fold. But even if the Conservatives defuse the EU issue, UKIP will challenge them on issues such as immigration.

The strategic incentives for niche parties differ from those for mainstream parties. In competition with the Conservatives, UKIP have employed both adversarial and non-competitive positions. In the former, UKIP highlights its distinctive position on the EU issue (and on immigration) and seeks to exploit Conservative difficulties. In the latter, UKIP appears to prioritise its policy objective by suggesting cooperation but is, in reality, still trying to make life difficult for its rival. We have also shown how a niche party has responded to a mainstream party's strategy of holding position, by both continuing to emphasise differences between the parties' positions and attempting to broaden its appeal in order to gain votes. Establishing whether these findings are specific to the case of a hard Eurosceptic niche party competing with a mainstream soft Eurosceptic party will require further research on niche party responses in other contexts. In the case studied here, the EU issue is the main driver of support for UKIP (Whitaker and Lynch, 2011; Ford et al, 2012) so the party should raise the salience of the issue, emphasise its radical position and highlight Conservative policy failings. Should the fiscal compact produce a sharp shift towards a two-tier EU in which the UK loses influence, party competition on the issue may harden into an 'in-out' debate in which the hard Eurosceptic position gains traction.

Niche parties find it difficult to shape the agenda and, with the EU issue of low salience to voters, UKIP has broadened its narrative. A tough position on immigration has become important to its appeal and populist messages tap into discontent with the main parties. The salience of immigration for voters and perceived failings of the main parties suggest that UKIP will exploit this as a positional issue. But aping the populist radical right's xenophobia would risk contaminating the party brand. UKIP is also developing neo-liberal and libertarian positions that 
are more radical than the Conservative position, although opinion polls suggest that many UKIP supporters have authoritarian views.

Competition between mainstream and niche parties will become more significant in general elections if, as Curtice (2010) suggests, the prospects of single party government have receded. Opinion polls show that the Conservatives are indeed leaking support to UKIP as the latter target Conservative supporters disillusioned by coalition policy on Europe, immigration and other issues. Rather than just being a minor irritant, UKIP may also threaten the Conservatives' prospects of winning a parliamentary majority.

\section{Notes}

1. Chi-squared tests of the representativeness of the samples compared with the population of the party's general election candidates confirmed that the UKIP survey is representative in terms of gender and region, and that the Conservative survey is representative in terms of gender. Support for the null hypothesis of no difference between the sample and population in terms of region was less strong $(\mathrm{p}=0.05)$ for the Conservatives and the sample under-represented incumbent MPs, who made up 15 per cent of respondents but 25 per cent of candidates.

2. UKIP is not included in the CMP data set for 2005 or 2010, http://manifestoproject.wzb.eu/. 3. See www.mzes.uni-mannheim.de/projekte/manifestos

4. The BNP's mean score, close to the centre of the left-right spectrum, arises because some experts place them on the left and others on the far right. 
5. The difference between Conservative candidates' self-placement and party placement is statistically significant at the $\mathrm{p}<0.05$ level; that between self-placement and party's voters and between party placement and party's voters are significant at the $p<0.01$ level.

6. The difference between candidates' self-placement and party placement is statistically significant at the $\mathrm{p}<0.05$ level; that between self-placement and party's voters and between party placement and party's voters are significant at the $\mathrm{p}<0.01$ level.

7. www.ipsos-mori.com/researchpublications/researcharchive/2435/European-Unionmembership-trends.aspx?view=wide

8. The data are available at www.bes2009-10.org/

9. In the 1999 survey, salience was measured on a 1-5 scale. The figure quoted here has been converted to a 1-4 scale to allow comparability with the 2010 data.

10. Data are available at www.essex.ac.uk/bes/BES2001.html

11. Data are available at www.essex.ac.uk/bes/

12. Some of the decline in salience when comparing the 2001 and 2005 BES data may be due to differences in the question asked. In 2001 voters were asked which was the most important issue 'in the general election' while in 2005 the question asked about the 'most important issue facing the country'. 
13. The difference in means for Conservative compared with UKIP voters is statistically significant at the $\mathrm{p}<0.001$ level.

14. Only voters who identified Europe/the euro as the most important issue were asked which party they thought could best deal with the issue.

15. We found a similar trend of increasing leakage from the Conservatives to UKIP by aggregating Ipsos-MORI's monthly political surveys from June 2010 to December 2011 into six month groupings. We are grateful to Roger Mortimore of Ipsos-MORI for providing these data. 


\section{References}

Abedi, A. and Lundberg, T. (2009) Doomed to failure? UKIP and the organisational challenges facing right-wing populist anti-political establishment parties. Parliamentary Affairs 62(1): 72-87.

Adams, J., Clark, M., Ezrow, L. and Glasgow, G. (2006) Are niche parties fundamentally different from mainstream parties? The causes and electoral consequences of Western European parties' policy shifts, 1976-98. American Journal of Political Science 50(3): 513-29.

Bakker, R., de Vries, C., Edwards, E., Hooghe,L., Jolly, S., Marks, G., Polk, J., Rovny, J., Steenbergen, M. and Vachudova, M. (2012) Measuring Party Positions in Europe: The Chapel Hill Expert Survey Trend File, 1999-2010. Unpublished manuscript. $\underline{\text { www.unc.edu/ hooghe/assets/data/pp/CHES_Trend_Paper_19_04_2012.pdf }}$

Bale, T. (2006) Between a soft and a hard place? The Conservative Party, valence politics and the need for a new 'Eurorealism'. Parliamentary Affairs 59(3): 385-400.

Bale, T., Green-Pedersen, C., Krouwel, A., Luther, K.R. and Sitter, N. (2010) If you can't beat them, join them? Explaining social democratic responses to the challenge from the populist radical right in Western Europe. Political Studies 58(3): 410-26.

Bethell, J. (2010) ANTIs - what next for the voters Westminster left behind? www.nothingbritish.com/wp-content/uploads/2010/11/ANTIs-full-doc.pdf Accessed 15 February 2012. 
Budge, I and Farlie, D. (1983) Explaining and Predicting Elections: Issue Effects and Party Strategies in Twenty-Three Democracies. London: Allen \& Unwin.

Cameron, D. (2009) A European Policy that People Can Believe In. Speech, London, 4 November.

Carey, S. and Geddes, A. (2010) Less is more: immigration and European integration at the 2010 general election. Parliamentary Affairs 63(4): 849-65.

Carlin, B. (2006) Off-the-cuff Cameron accuses UKIP of being 'fruitcakes and closet racists'. Daily Telegraph, 5 April.

Clements, B. and Bartle, J. (2009) The European issue and party choice at British general elections, 1974-2005. Journal of Elections, Public Opinion and Parties 19(4): 377-411.

Conservative Party (2010) Invitation to Join the Government of Britain. London: Conservative Party.

Conti, N. and Memoli, V. (2012) The multi-faceted nature of party-based Euroscepticism. Acta Politica 47(2): 91-112.

Cowley, P. and Stuart, M. (2012) The Cambusters: the Conservative European Union referendum rebellion of October 2011. Political Quarterly 83(2): 402-6.

Curtice, J. (2010) So what went wrong with the electoral system? The 2010 election and the debate about electoral reform. Parliamentary Affairs 63(4): 623-38. 
Curtice, J., Fisher, S. and Ford, R. (2010) Appendix 2: the results analysed. In D. Kavanagh and P. Cowley The British General Election of 2010. London: Palgrave, 2010.

Denver, D. (2010) The results: how Britain voted. Parliamentary Affairs 63(4): 588-606.

De Vries, C.E. (2007) Sleeping giant: fact or fiction. How European integration affects national elections. European Union Politics 8(3): 363-85.

De Vries, C.E. and Hobolt, S. (2012) When dimensions collide: the electoral success of issue entrepreneurs. European Union Politics 13(2): 246-68.

Downs, A. (1957) An Economic Theory of Democracy. New York: Harper \& Row.

Evans, G. (1998) Euroscepticism and Conservative electoral support: how an asset became a liability. British Journal of Political Science 28(4): 573-90.

Evans, G. (2002) European integration, party politics and voting in the 2001 election. British Elections and Parties Review 12: 95-110.

Ezrow, L. (2008) On the inverse relationship between votes and proximity for niche parties. European Journal of Political Research 47(2): 206-20.

Farage, N. (2010) Fighting Bull. London: Biteback. 
Ford, R., Goodwin, M.J. and Cutts, D. (2012) Strategic Eurosceptics and polite xenophobes: support for the UK Independence Party (UKIP) in the 2009 European Parliament elections. European Journal of Political Research 51(2): 204-34.

Forsyth, J. (2012) UKIP's new deal. The Spectator, 26 May, p.16.

Fresh Start Project (2012) Options for change green paper. Renegotiating the UK's relationship with the EU, July, www.eufreshstart.org/downloads/fullgreenpaper.pdf, accessed 25 July 2012.

Gabel, M. and Scheve, K. (2007) Mixed messages: party dissent and mass opinion on European integration. European Union Politics 8(1): 37-59.

Green, J. (2007) When voters and parties agree: valence issues and party competition. Political Studies 55(4): 629-55.

Green, J. (2011) A test of core vote theories: the British Conservatives, 1997-2005. British Journal of Political Science 41(4) 735-64.

Green, J. and Hobolt, S. (2008) Owning the issue agenda: party strategies and vote choices in British elections. Electoral Studies 27(4): 60-76.

Goodwin, M. and Evans, J. (2012) From Voting to Violence? Far Right Extremism in Britain. London: Hope not Hate.

Helm, T. (2004) Howard rages at UKIP 'gadflies'. Daily Telegraph, 31 May. 
Hooghe, L. and Marks, G. (2009) A post-functionalist theory of European integration: from permissive consensus to constraining dissensus. British Journal of Political Science 39(1): 1-23.

Lynch, P. and Whitaker, R. (forthcoming) Where there is discord, can they bring harmony? Managing intra-party dissent on European integration in the Conservative Party. British Journal of Politics and International Relations.

Lynch, P. Whitaker, R. and Loomes, G. (2011) The UK Independence Party: understanding a niche party's strategy, candidates and supporters. Parliamentary Affairs, advance online publication 9 November, doi:10.1093/pa/gsr042.

Marks, G., Hooghe, L., Steenbergen, M.R. and Bakker, R. (2007) Crossvalidating data on party positioning on European integration. Electoral Studies 26(1): 23-38.

Matilla, M. and Raunio, T. (2012) Drifting further apart: national parties and their electorates on the EU dimension. West European Politics 35(3): 589-606.

Meguid, B. (2005) Competition between unequals: the role of mainstream party strategy in niche party success. American Political Science Review 99(3): 347-59.

Montgomerie, T. (2012) David Cameron ignores UKIP at his peril. The Times, 11 April.

Mudde, C. (1999) The single-issue party thesis: extreme right parties and the immigration issue. West European Politics 22(3): 182-97. 
Mudde, C. (2008) Populist Radical Right Parties in Europe. Cambridge: Cambridge University Press.

Oppermann, K. (2008) The Blair Government and Europe: the policy of containing the salience of European integration. British Politics 3(2): 156-82.

Petrocik, J.R. (1996) Issue ownership in presidential elections, with a 1980 case study. American Journal of Political Science 40(3): 825-50.

Ray, L. (2007) Mainstream Euroskepticism: trend or oxymoron? Acta Politica 42(2-3): 153-72.

Rooduijin, M., de Lange, S.L. and van der Brug, W. (2012) A populist Zeitgeist? Programmatic contagion by populist parties in Western Europe. Party Politics, advance online publication 20 April, doi:10.1177/1354068811436065.

Rovny, J. (2012) Who emphasizes and who blurs? Party strategies in multidimensional competition. European Union Politics, 13(2): 269-92.

Sanders, D., Clarke, H.C., Stewart, M.C. and Whiteley, P. (2011) Downs, Stokes and the dynamics of electoral choice. British Journal of Political Science 41(4): 287-314.

Sparrow, A. (2011) Farage says UKIP could offer Tories electoral pact in return for referendum. The Guardian, 19 December.

Spoon, J.-J. (2009) Holding their own: explaining the persistence of Green parties in France and the UK. Party Politics 15(5): 615-34. 
Steenbergen, M.R. and Scott, D.J. (2004) Contesting Europe? The salience of European integration as a party issue. In G. Marks and M.R. Steenbergen (eds.) European Integration and Political Conflict. Cambridge: Cambridge University Press, pp.165-92.

Stokes, D.E. (1963) Spatial models of party competition. American Political Science Review 57(2): $368-77$.

Strøm, K. and Müller, W.C. (2000) Political parties and hard choices. In K. Strøm and W. C. Müller (eds.) Policy, Office or Votes? How Political Parties in Western Europe make Hard Decisions. Cambridge: Cambridge University Press, pp.1-35.

Taggart, P. and Szczerbiack, A. (2008) Theorising party-based Euroscepticism: problems of definition, measurement and causality. In P. Taggart and A. Szczerbiack (eds.) Opposing Europe. The Comparative Party Politics of Euroscepticism. Volume 2. Oxford: Oxford University Press, pp.238-62.

UK Independence Party (2010a) Restoring Britishness. London: UK Independence Party.

UK Independence Party (2010b) Empowering the People. London: UK Independence Party.

UK Independence Party (2011) What We Stand For. London, UK Independence Party.

Wagner, M. (2011) Defining and measuring niche parties. Party Politics, advance online publication 18 May, doi:10.1177/1354068810393267. 
Wagner, M. (2012) When do parties emphasise extreme positions? How strategic incentives for policy differentiation influence issue importance. European Journal of Political Research 51(1): 64-88.

Whitaker, R. and Lynch, P. (2011) Explaining support for the UK Independence Party at the 2009

European elections. Journal of Elections, Public Opinion and Parties 21(3): 359-79.

Word count: 10, 959.

Date of revised manuscript: 3 August 2012. 